\title{
Body and Organ Growth of the Springhare
}

\author{
Thomas M. BUTYNSKI ${ }^{1}$
}

\begin{abstract}
Butynski T. M., 1979: Body and organ growth of the springhare. Acta theriol., 24, 32: 431-448 [With 10 Tables \& 3 Figs.].

A total of 560 juvenile and adult springhares, Pedetes capensis (Forster, 1778) were collected, in the Republic of Botswana from August 1971 through August 1973. Linear and quadratic equations are presented to describe the growth rates of 28 body parts of male and female springhares relative to dried eye lens weight. Allometric equations, based on body weight, are used for intra- and interspecific comparisons of the relative growth rates of various body parts. Appendage length measurements were much less variable than either the length or weight measurements of the organs. A gradient from external appendages to internal organs existed for the attainment of full adult size. No sexual dimoriphism was apparent for external appendages. Liver and right kidney weights were significantly greater in females than in males. Pregnant females had significantly heavier livers than did nonpregnant adult females. There was little change in relative weight of the kidneys, heant and liver from the time of weaning until full adult size was attained. Kidney, heart, and liver weights were atypically low for mammals of this body size. Based upon their allometric equations, each body part measured could be classified as having one of three distinct growth patterns. Allometric constants for male and female heart and kidney weights were similar to those of other mature mammals while those for liver weight were considerably higher.

[Deipt. Wildlife, National Parks and Tourism, Gaborone, Botswana]
\end{abstract}

\section{INTRODUCTION}

The springhare Pedetes capensis (F o r s te r, 1778) is a large ( $3 \mathrm{~kg}$ ), bipedal, saltatorial rodent which inhabits much of the southern third of Africa (C o e, 1969, Dorst \& Dand elot, 1970; K ingdon, 1974). $P$. capensis is the only species in the Family Pedetidae (Burton \& B u rton, 1970; K ingdon, 1974). Springhares are of particular taxonomic interest in that they are related neither ancestrally, nor collaterally, to other rodents (W o o d, 1962) and their pre-Miocene history is not known (W o o d, 1974).

Except for the first few weeks after birth (H e diger, 1950; C o e, 1967; Rosenthal \& Meritt, 1973; Velte, in press), there is no published account concerning the growth characteristics of the spring-

1 Present address: New York Zool. Soc., Bronx Park, Bronx, New York, U.S.A. 10460. 
hare. This is surprising in light of the springhare's wide distribution, abundance, and considerable economic value (B utynski, 1973).

This paper provides representative data on body and organ measurements of normal healthy juvenile and adult springhares in central and southeastern Botswana, examines body and organ growth patterns and reiationships, and compares these growth data with those for several other mammalian species.

\section{STUDY AREAS}

From August 1971 through August 1973 monthly collections of springhares were made from two study areas about $180 \mathrm{~km}$ apart in the Republic of Botswana. The Kalahari Study Area was located in the remote Kutswe Game Reserve and southern portion of the Central Kalahari Game Reserve (latitudes $23^{\circ}-24^{\circ}$ South, and longitudes $24^{\circ}-25^{\circ}$ East), and the Eastern Botswana Study Area was sittuated on the outskirts of Gaborone (latitudes $24^{\circ}-25^{\circ}$ South, and longitudes $25^{\circ}-$ $26^{\circ}$ East). Smithers (1971), Butynski $(1975,1978)$, and Dawson \& But y nski (1975) provide general descriptions of these areas.

Although springhares collected on the Kalahari Study Area were slightly larger than those from the Eastern Study Area, these differences and the purpose of this analysis did not warrant their separate consideration.

\section{MATERIALS AND METHODS}

Springhares were located at night with the help of a spotlamp and were shot with a 12-gauge shotgun. A total of 319 springhares were collected on the Kalahari Study Area and 241 on the Eastern Study Area. The mean monthly sample from September 1971 through July 1973 for both areas combined was $24.2 \pm 1.6$ springhares. In addition, three animals were collected in August 1971 and two in August 1973.

Springhares first left the burrow to feed above ground when they attained a body weight of approximately $1.3 \mathrm{~kg}$ (B ut ynski, 1978). Thus, only those individuals weighing $1.3 \mathrm{~kg}$ or more were susceptible to collection by shooting. Weaning occurred soon after springhares began to feed above ground (B u t y n s ki, 1978); therefore, the sample upon which the following analysis is based consisted only of weaned and a few nearly-weaned individuals.

Eyes were removed from all specimens within three hours of death and fixed with $10 \%$ formal-saline. Springhares were either placed immediately in cold storage and frozen, or left out to cool overnight, placed in an ice box the following morning and transported to cold storage.

Springhares in Botswana bred year around and breeding peaks or changes in body weight were not apparent (B utynski, 1978). Therefore, annual changes in body weight resulting from pregnancy or changes in body condition were not important complicating factors in the present study.

Springhares were weighed to the nearest gram. External length measurements were taken to the nearest millimeter. "Tail length " is the distance from the upper base of the tail to the tip of the tail, not including the hairs; "ear length « is the length of the right ear from the notch at the lower end of the ear opening to the tip of the ear; "hind foot length" is the length of the right hind foot from the 
heel to the end of the middle toe nail; and mbody length " is the distance from the tip of the nose to the end of the tail, not including the tail hairs.

Testes, vasa defferentia, ovaries and vaginae were measured to the nearest millimeter. Heart, liver, kidney, testis, and seminal vesicle weights were taken to the nearest decigram (dg). External fat was removed from all organs prior to weighing.

Fixed eye lenses were removed from the eyes and placed in a convection drying oven. After drying to a constant weight the lenses were weighed to the nearest milligram. Eye lens weights referred to in this paper are for one lens as derived from the mean of the two dried eye lenses from each springhare.

Since known age materials were not available there was no way to establish the absolute age of the animals used in this study. Therefore, dried eye lens weight was used as an index for assessing relative growth rate and age of various body parts. Dried eye lens weight is a particularly good indicator of relative age in the springhare because of its considerable change in size during the life of this nocturnal mammal. Dried eye lens weight increased by a factor of eight, from $80 \mathrm{mg}$ at birth to more than $600 \mathrm{mg}$ in the soldest « individuals.

In juvenile and adult springhares the weight of the dried eye lens ranged from $158 \mathrm{mg}$ to $631 \mathrm{mg}$. This range was divided into $50 \mathrm{mg}$ increments and each of the 560 springhares was assigned to one of the ten resulting categories. Body and organ measurements were tabulated and subjected to statistical analyses using the CDC 6500 Computer at Michigan State University. Means and standard error of the means were obtained for sixteen parameters on males and twelve parameters on females in each of the ten categories of eye lens weight.

Regressions were used to analyse the growth rate of various parts of the body relative to eye lens weight. Relative growth rate values were obtained from the regression coefficient $b$ in the linear regression equation

$$
\mathrm{Y}=a+b(X)
$$

or from the coefficient $b_{1}$ in the quadratic regression equation

$$
Y=a+b_{1} X+b_{2} X^{2}
$$

The $b_{1}$ coefficient alone provided a suitable index of relative growth rate since the $b_{2}$ coefficient was always small and contributed little to the slope value.

In the linear and quadratic regression equations $Y$ is the weight or length of a body part, $a$ is the intercept constant, and $X$ is the dried eye lens weight in milligrams. The $b$ and $b_{1}$ coefficients are, therefore, the rate of increase of the dependent variable $Y$ (e.g., body length, heart weight) relative to that of the independent variable $X$ (eye lens weight). Although in most cases both linear and quadratic equations provided satisfactory predictive values for the variable under consideration, the equation yielding the higher correlation coefficient was chosen for presentation here.

In mammals the weight and length of body parts are frequently related to total body weight through power laws (allometry) ( $\mathrm{H} \mathrm{uxley,} \mathrm{1932;} \mathrm{Gould,} \mathrm{1966).}$ Statistical analysis reveals that allometric equations are reliable for estimating organ weights in animals ranging in size from mice $(25 \mathrm{~g})$ to steers $(1000 \mathrm{~kg})$ and possibly they also apply in elephants and whales (B rody, 1945; Sta h l, 1965). In this study the allometric predictive equation

$$
\mathrm{Y}=a X^{b}
$$


was used. B rody (1945) considers this to be the most satisfactory equation fo: relating part-to-part or to body weight in animals of different size. $Y$ is tht weight or length of a body part (dependent variable) and $X$ is the body weigh: (independent variable), $b$ is the growth ratio at which $Y$ increases relative to $X$, and is here referred to as the "constant of allometry " (Simpson, Roe \& Le. wontin, 1960). The $a$ coefficient denotes the value of $\mathrm{Y}$ when $\mathrm{X}^{b}$ equals 1 anc is called the winitial growth constant (T e is s i e r, 1960), $a$ and $b$ were calculated by the least squares regression of $\log _{10}$ transformed $Y$ and $X$ variables (B rody. 1945; S imps on et al., 1960).

Differences between means and between regression slopes were tested with $Z$. and $F$-statistics, respectively. Significance of the regression slopes and correlation coefficients were determined by $F$ - and $t$ - statistics, respectively. A value of $P<0.05$ was regarded as significant and $P<0.01$ as highly significant.

\section{RESULTS AND DISCUSSION}

\subsection{Body Measurements}

The overall coefficients of variation C.V. for juvenile and adult springhares (Tables $1 \&$ 2) indicate that external length measurements were not highly variable; the largest coefficient of variation being $8.7 \%$

Table 3

Coefficient constants $a$ and $b$, and correlation coefficients $r$ for the linear regression of several growth variables $Y$ on dried eye lens weight $X(\mathrm{mg})$ of male and female springhares. Size of samples as in Tables 1 and 2.

\begin{tabular}{lrccc}
\hline $\begin{array}{c}\text { Dependent } \\
\text { variable Y* }\end{array}$ & $\begin{array}{c}\text { Intercept } \\
\text { constant } \\
a\end{array}$ & $\begin{array}{c}\text { Slope constant } \\
b^{* *} \pm \text { S.E. }{ }^{* *}\end{array}$ & $\begin{array}{c}\text { Correlation } \\
\text { coefficient } \\
r\end{array}$ & $\begin{array}{c}\text { Coefficient of } \\
\text { determination } \\
r^{2}\end{array}$ \\
\hline & & FEMALES & & 0.0354 \\
Hind foot length (mm) & 151.5 & $0.0073 \pm 0.0023$ & 0.1882 & 0.4739 \\
Right kidney weight (dg) & 27.0 & $0.0593 \pm 0.0050$ & 0.6884 & 0.5706 \\
Left kidney weight (dg) & 23.7 & $0.0730 \pm 0.0052$ & 0.7554 & 0.2296 \\
Right ovary length (mm) & 5.5 & $0.0088 \pm 0.0010$ & 0.4791 & 0.2845 \\
Left ovary length (mm) & 5.2 & $0.0097 \pm 0.0009$ & 0.5334 & 0.0248 \\
& & MALES & & 0.5112 \\
Hind foot length (mm) & 151.3 & $0.0108 \pm 0.0041$ & 0.1575 & 0.7150 \\
Seminal vesicle wt. (dg) & -39.6 & $0.2332 \pm 0.0240$ & & \\
\hline
\end{tabular}

* $\mathrm{Y}=a+b(X)$. See Methods Section for details.

** Probability is $<0.008$ in all cases that the slope $b$ is not significantly different from zero.

*** S. E. $=$ standard error.

(female body length). Length measurements of parts of the reproductive tract exhibited far more variability; the coefficient of variation ranged from $18.0 \%$ for vagina length to $42.1 \%$ for left testis length.

Body weight had the lowest coefficient of variation $(17.3 \%$ in males) of the weight measurements taken. Weights of the reproductive organs showed the greatest variation with the highest coefficient of variation 
being that for the vesicular gland $(77.7 \%)$. The liver, in both males $(27.2 \%)$ and females $(32.9 \%)$, was the most variable of the visceral organs studied.

Table 4

Coefficient constants $a, b_{1}$ and $b_{2}$, and correlation coefficients $r$ for the quadratic regression of several growth variables $Y$ on dried eye lens weight $X(\mathrm{mg})$ of male and female springhares. Size of samples as in Tables 1 and 2.

\begin{tabular}{|c|c|c|c|c|c|}
\hline 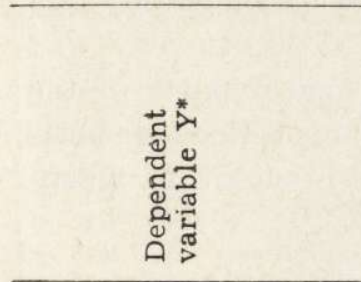 & 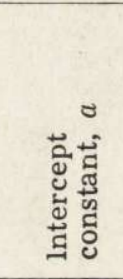 & 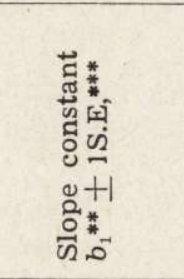 & 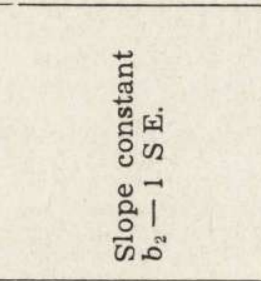 & 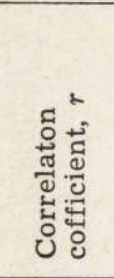 & 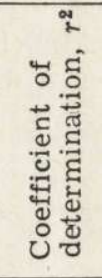 \\
\hline \multicolumn{6}{|c|}{ FEMALES } \\
\hline Body weight (g) & -104.5 & $12.51 \pm 0.84$ & $-0.0119 \pm 0.0011$ & 0.8829 & 0.7796 \\
\hline Body length (mm) & 511.6 & $1.34 \pm 0.19$ & $-0.0014 \pm 0.0003$ & 0.5794 & 0.3358 \\
\hline Tail length $(\mathrm{mm})$ & 288.2 & $0.67 \pm 0.09$ & $-0.0008 \pm 0.0001$ & 0.5028 & 0.2528 \\
\hline Ear length $(\mathrm{mm})$ & 63.0 & $0.03 \pm 0.01$ & $-0.0000 \pm 0.0000$ & 0.4273 & 0.1826 \\
\hline Heart weight (dg) & 17.8 & $0.30 \pm 0.07$ & $-0.0003 \pm 0.0001$ & 0.5498 & 0.3023 \\
\hline Liver weight (dg) & -202.4 & $3.24 \pm 0.65$ & $-0.0034 \pm 0.0009$ & 0.5525 & 0.3053 \\
\hline Vaginal length (mm) & 11.4 & $0.23 \pm 0.33$ & $-0.0002 \pm 0.0001$ & 0.5716 & 0.3267 \\
\hline \multicolumn{6}{|c|}{ MALES } \\
\hline Body weight (g) & 46.1 & $11.89 \pm 0.80$ & $-0.0116 \pm 0.0011$ & 0.8569 & 0.7343 \\
\hline Body length $(\mathrm{mm})$ & 583.2 & $1.00 \pm 0.10$ & $-0.0010 \pm 0.0001$ & 0.7142 & 0.5100 \\
\hline Tail length (mm) & 325.6 & $0.48 \pm 0.08$ & $-0.0005 \pm 0.0001$ & 0.4517 & 0.2041 \\
\hline Ear length $(\mathrm{mm})$ & 63.0 & $0.04 \pm 0.01$ & $-0.0000 \pm 0.0000$ & 0.4101 & 0.1682 \\
\hline Heart weight (dg) & -2.2 & $0.39 \pm 0.08$ & $-0.0004 \pm 0.0001$ & 0.6935 & 0.4809 \\
\hline Liver weight (dg) & 38.7 & $1.68 \pm 0.45$ & $-0.0015 \pm 0.0006$ & 0.5753 & 0.3310 \\
\hline Rt. kidney weight (dg) & 11.0 & $0.16 \pm 0.04$ & $-0.0001 \pm 0.0000$ & 0.6749 & 0.4555 \\
\hline Left kidney weight (dg) & ) 9.6 & $0.17 \pm 0.04$ & $-0.0001 \pm 0.0000$ & 0.7128 & 0.5080 \\
\hline Rt. vas deferens (mm) & -42.8 & $0.80 \pm 0.11$ & $-0.0008 \pm 0.0001$ & 0.7708 & 0.5941 \\
\hline Lt. vas deferens (mm) & -40.3 & $0.78 \pm 0.11$ & $-0.0007 \pm 0.0002$ & 0.7723 & 0.5964 \\
\hline Rt. testes weight (dg) & -168.2 & $0.96 \pm 0.12$ & $-0.0007 \pm 0.0002$ & 0.8370 & 0.7006 \\
\hline $\begin{array}{l}\text { Left testes } \\
\text { weight (dg) } \\
\text { R. tectes }\end{array}$ & -154.5 & $0.86 \pm 0.16$ & $-0.0004 \pm 0.0002$ & 0.8599 & 0.7394 \\
\hline length $(\mathrm{mm})$ & -41.7 & $0.35 \pm 0.03$ & $-0.0003 \pm 0.0000$ & 0.8794 & 0.7734 \\
\hline $\begin{array}{l}\text { Left testes } \\
\text { length }(\mathrm{mm})\end{array}$ & -40.2 & $0.34 \pm 0.04$ & $-0.0003 \pm 0.0001$ & 0.8760 & 0.7673 \\
\hline
\end{tabular}

* $\mathrm{Y}=a+b_{1}(X)+b_{2}\left(X^{2}\right)$. See Methods Section for details.

** Probability that the slope $b_{1}$ is not significantly different from $<0.02$ in all cases.

*** Standard Error.

Relative increase in size of each variable for springhares (i.e., range of values) indicated a trend similar to that observed above for the over all coefficient of variation (Tables 1 \& 2). External body length meas 
urements showed only a $17 \%$ (male hind foot) to $45 \%$ (female body length) increase in size from the lower range value to that for the upper range. Length measurements on various parts of the reproductive tract, however, indicated a $171 \%$ (vagina) to $689 \%$ (left testis) increase in size.

Body weight and the weights of visceral organs underwent a $197 \%$ (female body weight) to $646 \%$ (female liver weight) change. Reproductive organs exhibited a 74-(left testis) to 154-(vesicular gland) fold change in weight.

The high coefficients of variation and increase in size of parts of the reproductive tracts, particularly in the male, clearly reflect a postponement of growth and then rapid enlargement subsequent to weaning.

\subsection{Growth Equations}

Correlation coefficients $r$ for tail, ear and hind foot lengths in males and females (Tables $3 \& 4$ ) were the least satisfactory, reflecting the fact that $84 \%$ to $98 \%$ of the growth of these body parts was completed before animals were weaned and available to the collector. Less than $0.26 \%$ of the variation $r^{2}$ in tail and ear lengths, and less than $0.04 \%$ of the variation in hind foot length was explained by variation in eye lens weight. Highest correlation coefficients were obtained for body parts which showed the most persistent growth subsequent to weaning; most noticeably female body weight $(r=0.88)$, male body weight $(r=$ $0.86)$, and testis length $(r=0.88)$. More than $73 \%$ of the variation $r^{2}$ of these three parameters was determined by variation in eye lens weigth.

Among the $b$ coefficients the effect of sex was most noticeable for liver weight, indicating that the liver of the female springhare grew at a much greater rate, relative to eye lens weight, than did the liver of the male.

All of the regression coefficients $b \quad(P<0.02)$ and correlation coefficients $(P<0.01)$ presented in Tables 3 and 4 were positive and significant.

\subsection{Instantaneous Growth Rates}

Since all body parts measured on springhares were fitted to eye lens weight, the shape of growth curves based upon mean values from Tables 1 and 2 were similar, not only for body (Fig. 1) and testis length (Fig. 2 ), but for all of the body parts measured. The primary differences among mean growth curves were in the timing of the transition from 


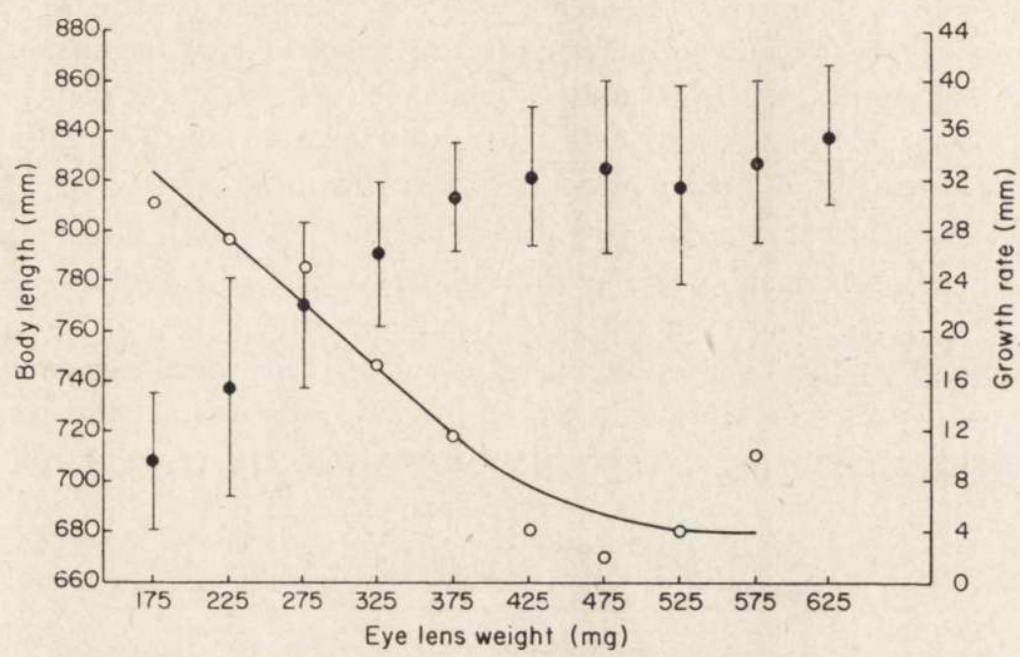

Fig. 1. Relationship in the male springhare of dried eye lens weight to mean length of the body (-) and growth rate of the body ( $\Delta$ body length $(\mathrm{mm}) / \Delta 50 \mathrm{mg}$ lens weigth) $(O)$. Trancepts represent one standard deviation. The growth rate curve is based upon a three point floating mean and was fitted by eye. Table 1 gives the size of the sample at each point.

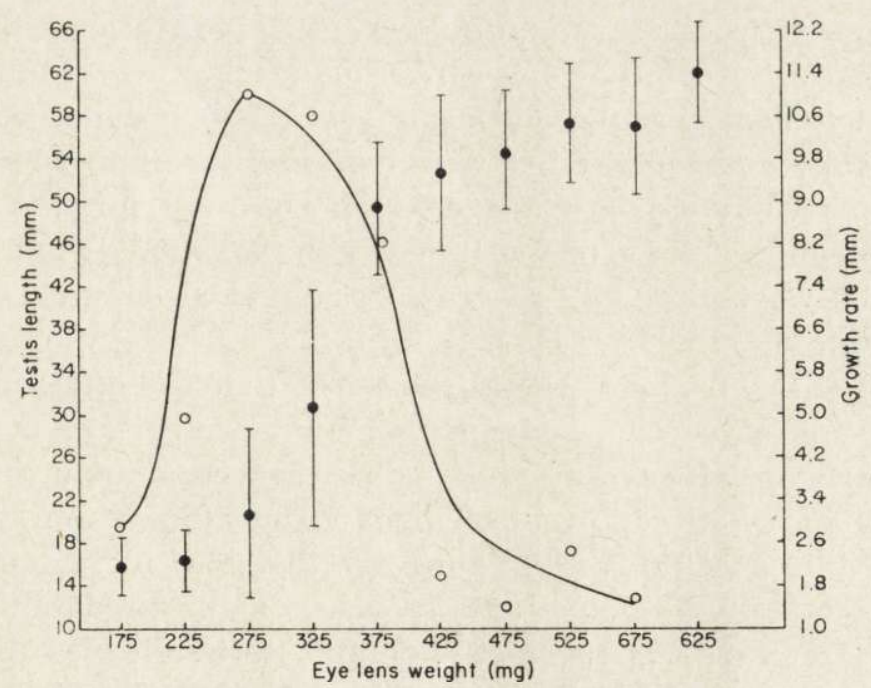

Fig. 2. Relationship in the male springhare of dried eye lens weight to mean length of the right testis (-) and growth rate of the right testis ( $\Delta$ testis length $(\mathrm{mm}) / \Delta 50 \mathrm{mg}$ lens weight) $(\bigcirc)$. See Fig. 1 for further details. 
linear to curvilinear growth, steepness, and flatness of the latter part of the curve. Mean growth curves for the reproductive organs of males differed somewhat in that they showed curvilinear growth prior to linear growth, reflecting the fact that rapid growth of the reproductive tract of males did not commence until after weaning.

Except for the organs of the reproductive tract of males, all body measurements taken showed instantaneous growth rate (velocity) curves similar to that for body length (Fig. 1), again differing mostly in their steepness and in the eye lens weight at which they became curvilinear. Because of their late and very rapid growth, the testes and vesicular glands yielded »bell-shaped " velocity curves (Fig. 2).

\subsection{Patterns of Growth}

In females, the liver, ovary, heart, kidney, and body weights continued to increase rapidly long after $95 \%$ of the potential body length was attained (Table 2, Fig. 3). Males showed the same general growth characteristics, but to a lesser degree (Table 1). The testes were the last organs to undergo rapid growth. Once rapid growth of the testes commenced, however, they showed the highest growth rate of any of the body parts studied. In males, the reproductive tract was the last part of the body to reach full-grown size.

There was a definite gradient from external parts (i.e., hind foot and ear lengths) to internal organs (especially testis length) as far as attainment of full-grown size was concerned (Fig. 3). At weaning (175 mg lens weight), when springhares began life above ground, body $(44 \%)$, eye lens $(26 \%)$, and testis $(3 \%)$ weights were still far below those of full-grown individuals and exhibited linear growth for a considerable time after weaning. Body $(82 \%)$, tail $(84 \%)$, ear $(93 \%)$, and hind feet $(98 \%)$ lengths were close to full-grown size and already showed curvilinear growth.

Fle a gle \& S a monds (1975) suggested that the differences in the growth schedule of various body parts may be important in determining which parts are affected by growth disturbances, namely, malnutrition or illness. This may also apply to springhares but, in addition, the growth schedule of this species further suggests that the individual is being structured to effectively detect and avoid the many predators in its environment (B u ty nski, 1978) at the time it first leaves the burrow.

The distribution of eye lens weights suggests that the age distribution was much the same for both male and female springhares (Tables $1 \& 2$ ) (B utynski, 1978). Upon this basis it seems justifiable to use the 
overall mean value of each body part for determining the occurrence and extent of sexual dimorphism (Table 5).

The five external measurements of springhares did not reveal any statistically significant sexual dimporphism (Table 5).

The overall mean weight of the liver of females was $80 \mathrm{~g}$ more than that of males. This difference was highly significant. Foetal weight was

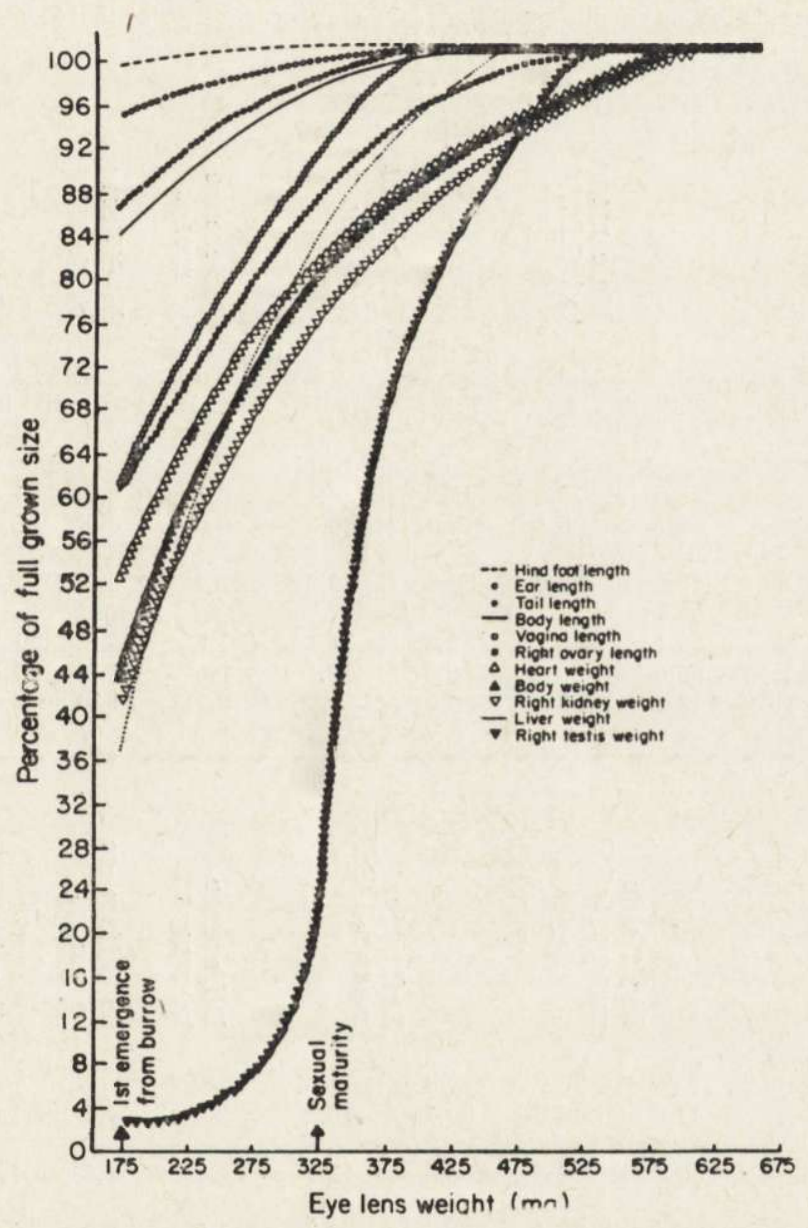

Fig. 3. Size of several body parts of the female springhare relative to dried eye lens weight from 150 to $650 \mathrm{mg}$. Changes in testis weight are also shown. See text for details.

not correlated with liver weight in those females with an eye lens weight greater than $400 \mathrm{mg}(r=0.07$, d.f. $=93, P>0.2)$. There was, however, a significant difference in mean liver weight between pregnant $(57 \mathrm{~g})$ and non-pregnant $(52 \mathrm{~g})$ adult females with an eye lens weight of more than $400 \mathrm{mg}(Z=1.90, P>0.03)$. Increase in liver weight with 
pregnancy has also been reported in both the albino rat Rattus norvegicus (M a c K a y, 1928) and the howler monkey $A$. caraya (M a l in o w et al., 1966).

Table 5

Comparison of male-female and right side-left side absolute mean values for various body parts of springhares. Size of samples as in Tables 1 and 2.

\begin{tabular}{|c|c|c|c|c|c|c|c|c|}
\hline 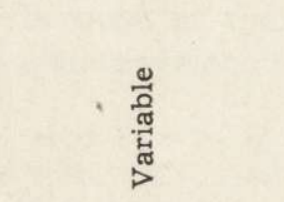 & & 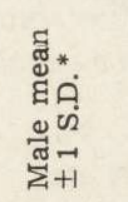 & & 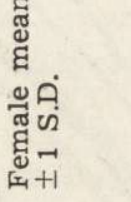 & 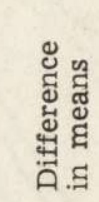 & 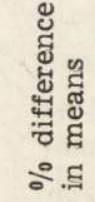 & 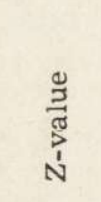 & 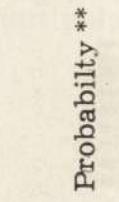 \\
\hline Body: weight (kg) & 2.72 & 0.47 & 2.78 & 0.53 & 0.06 & 2.2 & 1.415 & 0.156 \\
\hline Body length (cm) & $80.2 \pm$ & 4.4 & 79.7 & 6.9 & 0.5 & 0.6 & 1.013 & 0.312 \\
\hline $\begin{array}{l}\text { Tail length }(\mathrm{cm}) \\
\text { Hind foot }\end{array}$ & 42.3 & 2.6 & 41.7 & 2.9 & 0.6 & 1.4 & 1.685 & 0.093 \\
\hline length $(\mathrm{cm})$ & 15.5 & 0.8 & 15.4 & 0.4 & 0.1 & 0.6 & 1.876 & 0.060 \\
\hline Ear length (mm) & 7.1 & 0.3 & 7.1 & 0.3 & 0.0 & 0.0 & 0.000 & 1.000 \\
\hline $\begin{array}{l}\text { Right kidney } \\
\text { weight (dg) } \\
\text { Left kidney }\end{array}$ & 47.9 & \pm 10.0 & 50.3 & 9.8 & 2.4 & 5.0 & 2.092 & 0.037 \\
\hline $\begin{array}{l}\text { Left kidney } \\
\text { weight (dg) }\end{array}$ & 50.1 & \pm 10.2 & 52.0 & \pm 11.1 & 1.9 & 3.8 & 1.519 & 0.129 \\
\hline Heart weight (dg) & 88.6 & \pm 23.4 & 86.0 & \pm 18.1 & 2.6 & 3.0 & 1.082 & 0.280 \\
\hline Liver weight (dg) & 422.8 & \pm 115.0 & 502.5 & \pm 165.3 & 79.7 & 18.9 & 4.890 & $<0.0005$ \\
\hline
\end{tabular}

\begin{tabular}{|c|c|c|c|c|c|c|c|c|}
\hline 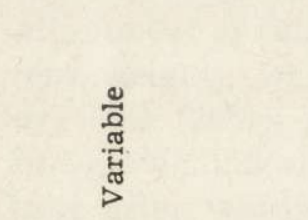 & & 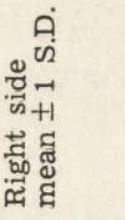 & & 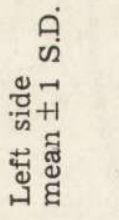 & 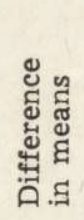 & 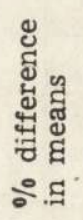 & 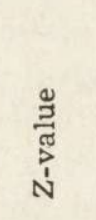 & 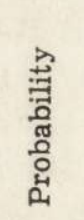 \\
\hline $\begin{array}{l}\text { Male kidney } \\
\text { weight (dg) } \\
\text { Female kidney }\end{array}$ & 47.9 & \pm 10.0 & 50.1 & \pm 10.2 & 2.2 & 4.6 & 1.829 & 0.067 \\
\hline $\begin{array}{l}\text { weight (dg) } \\
\text { Vas deferens }\end{array}$ & 50.3 & 9.8 & 52.0 & \pm 11.1 & 1.7 & 3.4 & 1.421 & 0.156 \\
\hline length $(\mathrm{mm})$ & 136.4 & \pm 37.4 & 135.4 & \pm 37.7 & 1.0 & 0.7 & 0.229 & 0.818 \\
\hline Testis weight (dg) & 90.9 & \pm 64.4 & 91.4 & \pm 70.0 & 0.5 & 0.6 & 0.072 & 0.944 \\
\hline Testis length (mm) & 43.4 & \pm 16.9 & 42.5 & \pm 17.9 & 0.9 & 2.1 & 0.511 & 0.610 \\
\hline Ovary length (mm) & 8.8 & \pm 2.1 & 9.0 & $\pm \quad 2.1$ & 0.2 & 2.3 & 1.109 & 0.267 \\
\hline
\end{tabular}

* Standard deviation

** Probability that means differ.

L a w e s \& G i l b e r t (1859) found that the liver increased in relative size as the physical condition of animals improved. This also appeared to be the case with springhares as both the physical condition of the 
pregnant springhare (Butynski, 1978) and the weight of the liver increased during gestation.

The mean value for the right kidney of females was significantly greater than for the males (Table 5). The difference between the mean lengths of the hind feet of males and females was almost significant $(\mathrm{P}=0.06)$, as was the difference between mean weights of the left and right kidneys of males $(P<0.07)$.

The mean body weights of males and females provided in Table 5 include the weight of the foetuses and stomach contents. Upon subtracting these weights, the mean body weight of the females became $2.68 \mathrm{~kg}$ and that of the male became $2.67 \mathrm{~kg}$.

\subsection{Relative Organ Weight}

There was little, if any, difference in weights of kidneys, heart, and liver, relative to body weight, between newly weaned male and female

Table 6

Organ weights of male and female springhares expressed as a percentage of body weight ( $\mathrm{g}$ organ weight/100 $\mathrm{g}$ body weight) for three different categories of dried eye lens weight. Size of samples as in Tables 1 and 2.

\begin{tabular}{lcccccccc}
\hline Sex & $\begin{array}{c}\text { Eye lens } \\
\text { weight }(\mathrm{mg})\end{array}$ & $\begin{array}{c}\text { Right } \\
\text { kidney } \\
(\%)\end{array}$ & $\begin{array}{c}\text { Left } \\
\text { kidney } \\
(\%)\end{array}$ & $\begin{array}{c}\text { Heart } \\
(\%)\end{array}$ & $\begin{array}{c}\text { Liver } \\
(\%)\end{array}$ & $\begin{array}{c}\text { Right } \\
\text { vesicular } \\
\text { gland } \\
(\%)\end{array}$ & $\begin{array}{c}\text { Right } \\
\text { testis } \\
(\%)\end{array}$ & $\begin{array}{c}\text { 'Left } \\
\text { testis } \\
(\%)\end{array}$ \\
\hline Male & $150-249$ & 0.19 & 0.20 & 0.34 & 1.61 & 0.01 & 0.02 & 0.02 \\
Male & $350-449$ & 0.17 & 0.18 & 0.34 & 1.61 & 0.20 & 0.38 & 0.40 \\
Male & $500-599$ & 0.18 & 0.19 & 0.34 & 1.55 & 0.24 & 0.49 & 0.54 \\
Female & $150-249$ & 0.18 & 0.19 & 0.34 & 1.53 & - & - & - \\
Female & $350-499$ & 0.17 & 0.18 & 0.30 & 1.81 & - & - & - \\
Female & $500-599$ & 0.19 & 0.19 & 0.30 & 1.75 & - & - & - \\
\hline
\end{tabular}

springhares (150 - $249 \mathrm{mg}$ lens weight) and fully-grown individuals (500_ $599 \mathrm{mg}$ lens weight) (Table 6). This was in contrast to the vesicular gland and testis, both of which underwent a 24 -fold increase in relative weight as springhares attained full size.

Mean organ weights of adult springhares and ten other similar-sized mammalian species belonging to four different Orders ( C r i l e \& Q u i rin g, 1940) where compared (Table 7). Although the small sample sizes for the other species must be considered, the mean relative weights of the kidneys, heart and liver in adult male and female springhares are generally lower than in the other species, in many cases strikingly so. 


\subsection{Organ Weight Allometric Equations}

Kidney, heart and liver weights, as predicted by the general mammalian organ weight allometric formulas ( $\mathrm{B} \mathrm{rod} \mathrm{y,} \mathrm{1945),} \mathrm{were} \mathrm{calcula-}$ ted for male and female springhares in the 500-549 mg eye lens weight category (Table 8). In all six comparisons the observed organ weight was only $50 \%$ to $63 \%$ of the predicted general organ weight for mam-

\section{Table 7}

Comparisons of relative kidney, heart, and liver weights of adult springhares and ten other mammalian species of similar body weight.

\begin{tabular}{|c|c|c|c|c|c|c|c|}
\hline 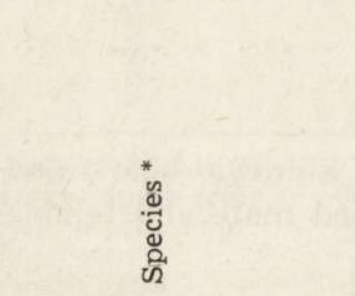 & 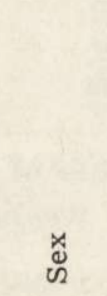 & 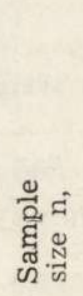 & 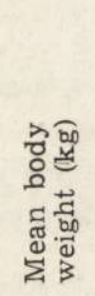 & 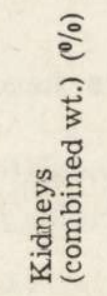 & 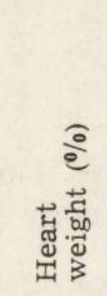 & 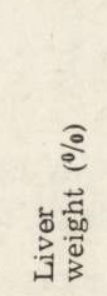 & 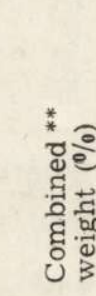 \\
\hline Pedetes capensis & M & 53 & 3.07 & 0.364 & 0.353 & 1.550 & 2.267 \\
\hline Pedetes capensis & $\mathrm{F}$ & 35 & 3.18 & 0.359 & 0.286 & 1.082 & 1.727 \\
\hline Erithizon dorsatum & M & 1 & 3.41 & 1.114 & 0.455 & 3.167 & 4.736 \\
\hline Erithizon dorsatum & F & 1 & 2.80 & 0.963 & 0.700 & 4.000 & 5.663 \\
\hline Dasyprocta punctata & M\&F & 2 & 3.17 & 0.485 & 0.553 & 2.681 & 3.719 \\
\hline Cuniculus paca & M\&F & 3 & 3.63 & 0.625 & 0.444 & 5.152 & 6.221 \\
\hline Lepus capensis & F & 1 & 2.93 & 0.416 & 1.024 & 1.772 & 3.212 \\
\hline Lepus arcticus & M & 2 & 1.90 & 0.964 & 1.094 & 2.470 & 4.528 \\
\hline Lepus arcticus & $\mathrm{F}$ & 2 & 2.64 & 1.015 & 1.497 & 3.479 & 5.991 \\
\hline Felis domesticus & M & 5 & 3.78 & 1.177 & 0.445 & 3.354 & 4.976 \\
\hline Felis domesticus & $\mathrm{F}$ & 2 & 2.88 & 0.765 & 0.429 & 3.212 & 4.406 \\
\hline Octocyon megalotis & F & 1 & 3.34 & 0.955 & 0.738 & 3.743 & 5.436 \\
\hline Aloutta palliata & $M \& F$ & 6 & 3.12 & 0.684 & 0.250 & 3.783 & 4.717 \\
\hline Cercopithecus aethiops & M & 4 & 3.96 & 0.380 & 0.809 & 2.179 & 3.368 \\
\hline Cebus capucinus & $\mathrm{M} \& \mathrm{~F}$ & 14 & 3.10 & 0.461 & 0.600 & - & - \\
\hline
\end{tabular}

* Except for springhares all values taken from Crile \& Quiring (1940). Data for those ten species closest to the springhare in body weight are presented.

** Combined relative weights of the kidneys, heart and liver.

mals. The data (Tables $7 \&$ 8) show that kidney, heart, and liver weights of springhares were atypically low for mature mammals of this body size. This may be related in some way to the body form, bipedal-saltatory locomotion, and/or arid environment of the springhare.

Predictive allometric size equations for various body parts of juvenile and adult male and female springhares (Table 9) were good predictors of size in all cases except for testis and vesicular gland weight. That the weights of the testis and vesicular gland were not adequately described by a single allometric equation is undoubtedly due to the delayed and then sudden and rapid growth of these two organs sub- 
sequent to weaning. Separate allometric equations for different periods of growth are probably necessary to adequately describe the change in size of these two organ in juvenile and adult springhares.

Based upon its allometric equation (Table 9), each body part can be placed into one of three growth-pattern classes:

External Linear - body, tail, hind feet and ear length,

- low allometric constant $(0.02<b<0.25)$ which is significantly less than 1.0 and which may not be significantly different from 0.0 (e.g., hind foot),

- little variability as expressed by the low standard error of the allometric constant $b(0.01<1$ S.E. $<0.04)$,

Table 8

Predicted and observed heart, liver, and kidney weights for male and female springhares in the $500-549 \mathrm{mg}$ category of eye lens weight. Predictive values were derived from the organ weight allometric formulas for mammals in general

$$
\text { (B r o d y, 1945). }
$$

\begin{tabular}{|c|c|c|c|c|c|}
\hline & & MALES & & FEMALES & \\
\hline & $\begin{array}{r}\text { Predicted } \\
\text { weight (dg) }\end{array}$ & $\begin{array}{l}\text { Observed Observed: } \\
\text { weight }(\mathrm{dg}) \text { Predicted }\end{array}$ & $\begin{array}{l}\text { Predicted } \\
\text { weight (dg) }\end{array}$ & $\begin{array}{l}\text { Observed } \\
\text { weight (dg) }\end{array}$ & $\begin{array}{l}\text { Observed: } \\
\text { Predicted }\end{array}$ \\
\hline
\end{tabular}

Kidneys

(combined wt.) 18.8

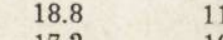

$17.2-10.8$

Liver weight

$\begin{array}{lll}88.4 & 47.6 & 0.54\end{array}$

$\begin{array}{lrrr}0.60 & 19.5 & 11.4 & 0.58 \\ 0.63 & 18.0 & 9.0 & 0.50 \\ 0.54 & 91.1 & 56.4 & 0.62\end{array}$

Male Reproductive Organs - testis length, and testis and vesicular gland weight,

- high allometric constant $(2.3<b<6.8)$ which is significantly greater than 1.0 ,

-- considerable variability as expressed by the relatively high standard error of the allometric constant $b(0.16<1$ S.E. $<0.41)$,

Intermediate - vas deferens, vagina and ovary length, and kidney, heart, and liver weight,

- allometric constant near $1.0(0.59<b<0.34)$ and often not significantly different from 1.0 ,

- moderate variability as indicated by the intermediate standard error of the allometric constant $b(0.03<1$ S.E. $<0.08)$.

The most important points presented in Table 9 are that, following weaning, external linear measurements decreased allometrically in relation to body weight. The reproductive organs of males showed a rate of size change which was more than six-fold that of body weight, while the visceral organs and parts of the reproductive tract of females dis- 
played the most persistent increase allometrically relative to body weight, often with a growth pattern similar to that of body weight (i.e., $b$ approximates 1.0 ).

Table 9

Allometric equations of the form $Y=a X^{b}$ where $X$ is the body weight $(\mathrm{kg})$. Equations predict the length or weight of various body parts $Y$ of juvenile and adult springhares $(150-600 \mathrm{mg}$ lens weight). Equations were derived from the nean values for each $50 \mathrm{mg}$ category of eye lens weight as presented in Tables 1 and 2 .

\begin{tabular}{|c|c|c|c|c|c|c|}
\hline $\begin{array}{c}\text { Dependent variable } \\
\text { Y }\end{array}$ & Sex & $\begin{array}{c}\text { Initial } \\
\text { growth } \\
\text { constant } \\
a\end{array}$ & $\begin{array}{c}\text { Allometric } \\
\text { constant } \\
b \pm 1 \text { S.E.* }\end{array}$ & & $\begin{array}{l}\text { elation } \\
\text { ficient } \\
\qquad P^{* *}\end{array}$ & Grow:h *** \\
\hline Body length $(\mathrm{cm})$ & M & 62.8 & $0.25 \pm 0.01$ & 0.99 & $<0.001$ & - \\
\hline & $\begin{array}{c}\mathrm{F} \\
\mathrm{M}\end{array}$ & $\begin{array}{l}62.0 \\
34.2\end{array}$ & $\begin{array}{l}0.42 \pm 0.01 \\
0.22 \pm 0.02\end{array}$ & $\begin{array}{l}0.98 \\
0.94\end{array}$ & $\leq 0.001$ & $\overline{-}$ \\
\hline Tall length $(\mathrm{cm})$ & $\mathrm{F}$ & 34.9 & $0.18 \pm 0.02$ & $\begin{array}{l}0.94 \\
0.88\end{array}$ & $\begin{array}{l}<0.01 \\
<0.05\end{array}$ & $\overline{-}$ \\
\hline Hind foot $(\mathrm{cm})$ & M & 15.2 & $0.02 \pm 0.01$ & 0.36 & $>0.50$ & - \\
\hline & & 14.9 & $0.03 \pm 0.04$ & 0.86 & $<0.05$ & - \\
\hline Ear length $(\mathrm{cm})$ & $\begin{array}{c}\text { M } \\
\text { F }\end{array}$ & 6.6 & $0.08 \pm 0.01$ & 0.82 & $<0.05$ & - \\
\hline Right kidney (dg) & $\begin{array}{l}\mathrm{F} \\
\mathrm{M}\end{array}$ & $\begin{array}{r}6.5 \\
21.1\end{array}$ & $\begin{array}{l}0.09 \pm 0.01 \\
0.84 \pm 0.02\end{array}$ & $\begin{array}{l}0.91 \\
0.99\end{array}$ & $\begin{array}{l}<0.05 \\
<0.001\end{array}$ & - \\
\hline & $\mathrm{F}$ & 17.9 & $1.00 \pm 0.05$ & 0.98 & $<0.001$ & 0 \\
\hline Left kidney (dg) & M & 20.9 & $0.89 \pm 0.02$ & 0.99 & $<0.001$ & - \\
\hline Heart weight (dg) & $\begin{array}{l}\mathrm{F} \\
\mathrm{M}\end{array}$ & $\begin{array}{l}17.6 \\
32.9\end{array}$ & $\begin{array}{l}1.04 \pm 0.05 \\
1.01 \pm 0.06\end{array}$ & $\begin{array}{l}0.98 \\
0.97\end{array}$ & $\begin{array}{l}<0.001 \\
<0.01\end{array}$ & i \\
\hline & $\mathrm{F}$ & 38.4 & $0.79 \pm 0.03$ & 0.99 & $<0.001$ & $\underline{0}$ \\
\hline Liver weight (dg) & M & 171.0 & $0.92 \pm 0.05$ & 0.98 & $<0.001$ & 0 \\
\hline Right vas deferens $(\mathrm{mm})$ & $\begin{array}{c}\mathrm{F} \\
\mathrm{M}\end{array}$ & $\begin{array}{r}132.8 \\
39.4\end{array}$ & $\begin{array}{l}1.28 \pm 0.04 \\
1.24 \pm 0.06\end{array}$ & $\begin{array}{l}0.99 \\
0.98\end{array}$ & $\begin{array}{l}<0.001 \\
<0.001\end{array}$ & $\begin{array}{l}+ \\
+\end{array}$ \\
\hline Left vas deferens $(\mathrm{mm})$ & M & 36.4 & $1.34 \pm 0.08$ & 0.98 & $<0.001$ & + \\
\hline Right vesicular gland (mm) & M & 0.03 & $6.83 \pm 0.32$ & 0.98 & $<0.001$ & + \\
\hline Right testis weight $\mathrm{dg}$ ) & M & 0.08 & $6.60 \pm 0.40$ & 0.97 & $<0.01$ & + \\
\hline Left testis weight dg) & M & 0.1 & $6.30 \pm 0.41$ & 0.97 & $<0.01$ & + \\
\hline Right testis length $\mathrm{mm}$ ) & M & 4.0 & $2.32 \pm 0.17$ & 0.96 & $<0.01$ & + \\
\hline Left testis length $(\mathrm{mm})$ & M & 3.9 & $2.38 \pm 0.16$ & 0.96 & $<0.01$ & + \\
\hline Vagina length $(\mathrm{mm})$ & $\mathrm{F}$ & 3.0 & $0.68 \pm 0.03$ & 0.99 & $<0.001$ & - \\
\hline Right ovary length ( $\mathrm{mm}$ ) & $\mathrm{F}$ & 4.8 & $0.61 \pm 0.06$ & 0.94 & $<0.01$ & - \\
\hline Left ovary length $(\mathrm{mm})$ & F & 4.9 & $0.59 \pm 0.06$ & 0.92 & $<0.01$ & - \\
\hline
\end{tabular}

* One standard error.

** Probability that the correlation coefficient is not significantly different from zero.

*** $(0)=$ organ grows at the same rate as the body, i.e. the allometric constant is not significantly different from $1.0,(+)=$ the rate of growth of the organ is significantly greater than that of the body, $(-)=$ the rate of growth of the organ is significantly less than that of the body.

Data available on the size-allometric relationships of the organs of "mature mammals in general " ( B rody, 1945) and "mature primates in general ( $\mathrm{S} \mathrm{ta} \mathrm{h} \mathrm{l,} \mathrm{1965)} \mathrm{to} \mathrm{body} \mathrm{weight} \mathrm{do} \mathrm{not} \mathrm{permit} \mathrm{statistical} \mathrm{test-}$ ing of the allometric equations with those for mature springhares (Table 10). However, the standard error of the allometric constants $b$ and the 
level of significance of the correlation coefficients $r$ provide some indication of the significance of the difference between allometric constants $b$. Heart weight and kidney weight allometric constants $b$ were significantly higher in male than in female springhares $(P<0.03$ and $P<0.005$, respectively). Kidney and heart allometric constants $b$ for males were similar (within 1 standard error) to those for other mammals in general, while those for females were more than two standard errors

Table 10

Allometric equations of the form $Y=a X^{b}$ where $X$ is body weight $(\mathrm{kg})$. Comparison of the allometric constant $b$ for kidney, heart, and liver weights $Y$ of mature male and female sprighares, mature mammals in general, and mature primates in general.

\begin{tabular}{|c|c|c|c|c|c|c|}
\hline $\begin{array}{c}\text { Organ \& } \\
\text { animal }\end{array}$ & Sex & $\begin{array}{l}\text { Initial } \\
\text { growth } \\
\text { constant }\end{array}$ & $\begin{array}{l}\text { Allometric } \\
\text { constant } \\
\pm 1 \text { S.E. }\end{array}$ & $\begin{array}{c}\text { Correlation } \\
\text { coefficient }\end{array}$ & Growth *** & $\begin{array}{l}\text { Sample } \\
\text { size }\end{array}$ \\
\hline $\mathrm{Y}$ & & $a$ & $b$ & $r$ & & $n$ \\
\hline \multicolumn{7}{|l|}{ Kidney weight (g) } \\
\hline Springhares & $\begin{array}{c}\mathrm{M} \\
\mathrm{F}\end{array}$ & $\begin{array}{l}4.15 \\
4.60\end{array}$ & $\begin{array}{l}0.88 \pm 0.04 \\
0.76 \pm 0.03\end{array}$ & $\begin{array}{l}0.55 \\
0.51\end{array}$ & $\bar{z}$ & $\begin{array}{r}81 \\
115\end{array}$ \\
\hline Mammals * & $M \& F$ & 7.3 & $0.85 \pm 0.01$ & 0.99 & - & $>100$ \\
\hline Primates $* *$ & $\mathrm{M} \& \mathrm{~F}$ & 6.3 & $0.87 \pm 0.04$ & 0.95 & - & 268 \\
\hline \multicolumn{7}{|l|}{ Heart weight (g) } \\
\hline Springhares & $\underset{\mathrm{F}}{\mathrm{M}}$ & $\begin{array}{l}3.63 \\
3.83\end{array}$ & $\begin{array}{l}0.92 \pm 0.06 \\
0.76 \pm 0.05\end{array}$ & 0.49 & 0 & 87 \\
\hline Mammals & $\mathrm{M} \& \mathrm{~F}$ & 5.8 & $0.98 \pm 0.01$ & 0.99 & $\overline{-}$ & $\begin{array}{r}127 \\
>100\end{array}$ \\
\hline Primates & $M \& F$ & 5.2 & $0.97 \pm 0.02$ & 0.99 & 0 & 321 \\
\hline \multicolumn{7}{|l|}{ Liver weight (g) } \\
\hline Springhare & $\begin{array}{l}\text { M } \\
\text { F }\end{array}$ & $\begin{array}{l}11.65 \\
10.65\end{array}$ & $\begin{array}{l}1.28 \pm 0.06 \\
1.43 \pm 0 \cap 5\end{array}$ & $\begin{array}{l}0.50 \\
0.51\end{array}$ & $\begin{array}{l}+ \\
+\end{array}$ & $\begin{array}{r}87 \\
193\end{array}$ \\
\hline Mammals & $\mathrm{M} \& \mathrm{~F}$ & 33.3 & $0.87 \pm 0.01$ & 0.99 & - & $>100$ \\
\hline Primates & $\mathrm{M} \& \mathrm{~F}$ & 32.2 & $0.93 \pm 0.02$ & 0.98 & - & 243 \\
\hline
\end{tabular}

* From B r o d y (1945), for mice to steers or larger mammals.

** From S t a h 1 (1965), based on primates from tree shrews to gorillas.

*** As for Table 9.

lower. Liver weight allometric constants $b$ were also significantly different for male and female springhares $(P<0.005)$ and several standard errors higher than the liver allometric constants $b$ for mammals in general. All correlation coefficients $r$ in Table 10 were significant at the 0.01 level.

In mature springhares the kidney and heart increased in weight at a rate which was approximately $90 \%$ of the rate of the body weight increase in males, and $76 \%$ in females. Liver, in contrast, showed positive allometry in mature springhares, increasing in weight at a rate which was $28 \%$ and $43 \%$ greater than the rate of body weight increase in males and females, respectively. 
The high allometric constants $b$ for liver were the most surprising results here; especially since it has been shown that the relative weight. of the liver decreased with increasing body weight in the albino rat (W ebster, Lil jegren \& Zimmer, 1947), guinea pig Cavia porcellus (W e bster \& Lil je gre n, 1949), beagle Canis familiaris (D e avers, Huggins \& S mith, 1972), and mammals in general (B rod y, 1945).

Acknowledgements: This research was undertaken as a cooperative effort among the Botswana Department of Wildlife, National Parks and Tourism, the United States Peace Conps and Michigan State University. I am indebted to Drs. R. Dukelow and T. Kuehl of the Michigan State University Endocrine Research Unit for much of the computer analysis. I am most grateful to C. Boggs, S. McMahon, Mattingly, and Drs. G. Petrides, R. Baker, J. King, and D. Ullrey, all of Michigan State University, for reviewing the manuscript. Sincere thanks are extended to A. Campibell, L. Birch and Dr. von Richter of the Botswana Department of Wildlife, National Parks and Tourism for their support through several difficult periods.

\section{REFERENCES}

1. Brody S., 1945: Bioenergetics and Growth. Reinhold: New York.

2. Burton M. \& Burton R., 1970: The International Wildlife Encyclopedia: Volume 17. Cavendish Corp., New York.

3. Butynski T. M., 1973: Life history and economic value of the springhare, Pedetes capensis (Forster), in Botswana. Botswana Notes \& Records, 5: 209-213.

4. Butynski T. M., 1975: Nocturnal ecology of the springhare, Pedetes capensis, in Rotswana. Michigan State University, M. S. thesis, Fisheries and Wildlife: $1-5.5$.

5. Butynski T. M., 1978: Ecological studies on the springhare, Pedetes capensis, in Rotswana. Michigan State University, Ph. D. thesis, Fisheries and Wildlife: $1 \rightarrow 181$.

6. C o e M. J., 1967: Preliminary notes on the eastern Kenya springhare, Pedetes surdaster larvalis Hollister. E. Afr. Wildl. J., 5: 174-177.

7. Coe M. J., 1969: The anatomy of the reproductive tract and breeding in the springhare, Pedetes surdaster larvalis Hollister. J. Reprod. Fert., Suppl. 6:$159-174$.

8. Crile G. \& Quiring D. P., 1940: A record of the body weight and certain organ and gland weights of 3690 animals. Ohio J. Sci., 40: 219-259.

9. Daws on J. \& Butynski T. M., 1975: The Kutse Game Reserve: Preserving. the Kalahari ecosystem. Biol. Conser., 7: 147 -153.

10. De a vers S., Huggins R. A. \& Smith E. L., 1972: Absolute and relative organ weights of the growing beagle. Growth, 36: 195-208.

11. Dorst J. \& Dandelot P. D., 1970: A Field Guide to the Larger Mammals of Africa. Collins, London.

12. Fleagle J. G. \& S a monds K. W., 1975: Physical growth of Cebus monkeys (Cebus albifrons) during the first year of life. Growth, 39: 35-52.

13. Flux J. E. C., 1970: Life history of the mountain hare (Lepus timidus scoticus): in north-east Scotland. J. Zool., Lond., 161: 75-123.

14. Gould S. J., 1966: Allometry and size in ontogeny and phylogeny. Biol. Rev., 41: $587-640$. 
15. Hediger H., 1950: Gefangenschaftsgeburt eines afrikanischen Springhasen. Pedetes caffer. Zool. Garten, 17: 166-169.

16. Huxley J. S., 1932: Problems of Relative Growth. Methuen \& Co., London.

17. Kingd on J., 1974: East African Mammals: Volume II, part B. (Hares and Rodents). Academic Press: 343-704. London.

18. Lawes J. B. \& Gilbert J. H., 1859: Experimental inquiry into the compo-, sition of some of the animals fed and slaughtered as human food. Phil. Trans. R. Soc., 2: $494-680$.

19. M a c K a y L.L., 1928: Factors which determine renal weight. IV. Pregnancy and lactation. Am. J. Physiol., 86: 215-224.

20. Malinow M. R. \& Corcoran A., 1966: Growth of the lens in howler monkeys (Alouatta caraya). J. Mammal., 47: 58-63.

21. Malinow M. R., Stahl W. R., Maruffo C. A., Pope B. L. \& Dep a oli R., 1966: Growth in howler monkeys. Primates, 7: 433-447.

22. Rosenthal M. \& Meritt D., 1973: Hand-rearing springhase at Lincoln Park Zoo. Int. Zoo Yrb., 13: 135-137.

23. Simpson G. G., Roe A. \& Lewontin R. C., 1960: Quantitative Zoology. Harcourt, Brace \& Co., New York.

24. Smithers R. H. N., 1971: The Mammals of Botswana. Museum Memoir No. 4. Mardon Printers, Salisbury.

25. Smuts G. L., 1974: Age determination in Burchell's zebra (Equus burchelli antiquorum) from the Kruger National Park. J. Sth. Afr. Wildl. Mgmt. Ass., 4: $103-115$

26. Stah1 W. R., 1965: Organ weights in primates and other mammals. Science, 150: $1039-1042$.

27. Teisser G., 1960: Relative growth. [In: «The Physiology of Crustacea», T. H. Waterman, ed.]. Academic Press, New York.

28. Velte F. F., (in press): Hand-rearing springhare Pedetes capensis. Int. Zoo Yrb.

29. Webster S. H. \& Liljegren E. J., 1949: Organ:body weight ratios for certain organs of laboratory animals. II. Guinea pig. Am. J. Anat., 85: 199-236

30. Webster S. H., Liljegren E. J. \& Zimmer O. J., 1947: Organ:body weight ratios for liver, kidneys and spleen of laboratory animals. I. Albino rat. Am. J. Anat., 81: 477-513.

31. Wood A. E., 1962: The juvenile tooth patterns of certain African rodents. J. Mammal., 43: 310-322.

32. Wood A. E., 1974: The evolution of the Old World and New World Hystricomorphs. Symp. Zool. Soc. Lond., 34: 21-60.

Accepted, June 2, 1979. 
Thomas M. BUTYNSKI

\section{WZROST CIAEA I ORGANOW WEWNETRZRNYCH U POSTRZAEKI}

\section{Streszczenie}

Przebadano ogółem 560 młodych i dorosłych postrzałek, Pedetes capensis (F o rster, 1778) złowionych w Botswanie, w latach 1971-1973. Badano tempo wzrostu ciała i organów wewnętrznych i ich wzajemne związki oraz porównnywano $\mathrm{z}$ danymi i dla innych gatunków ssaków.

Stwierdzono, że ciężar i wymiary długości (ciała, ogona, stopy i ucha) samców i samic (Tabela 1, 2) nie były tak zmienne jak wymiary organów rozrodezych, których współezynnik zmienności jest wysoki. Spośród badanych organów wewnętrzmych najbardziej zmienna była wątroba.

Tempo wzrostu 28 części ciała samców i samic postrzałek w porównaniu du zmian ciężaru soczewek, przedstawiają równania regresji liniowej (Tabela 3) i nieliniowej (Tabela 4). Wzrost ten przebiegał według krzywych podobnych do przedstawionych na Ryc. 1 i 2 . Różnice polegały między innymi na nachyleniu końcowej części krzywych. $\mathrm{Z}$ wyjątkiem organów rozrodczych samców, wszystkie inne części ciała wskazywały na szybkie tempo wzrostu, podobne do tempa wzrostu długości ciała (Ryc. 1). Jądra i pęcherzyki nasienne zaczęły rosnąć znacznie później i wzrost ten przebiegal bardzo gwałtownie. Krzywe ich wzrostu przybierały postać „dzwonowatą" (Ryc. 2).

Pięć zewnętrznych pomiarów ciała nie potwierdza istnienia dymorfizmu płciowego (Tabela 5). Samice miały istotnie większe ciężary wątroby i prawych nerek, niż samce. Ciężary wątroby były istotnie wyższe u samic ciężarnych. Między samcami i samicami, badanymi tuż po wykarmieniu, a osobnikami w pełni wyrośniętymi są małe różnice $w$ ciężarach serca i wątroby (Tabela 6). Natomiast ciężar jąder i wątroby powiększał się w tym czasie 24-krotnie. Srednie względnc ciężary nerek, serca i wątroby samców i samic postrzałek są ogólnie niższe niż u 10 innych gatunków ssaków odpowiadających im wielkością (Tabela 7). Ciężary te stanowily tylko $50-63 \%$ ciężarów przewidzianych przez ogólne alometryczne wzory dla ciężarów organów wewnętrznych ssaków (Tabela 8). Wielkości wyliczone z równań alometrycznych dla różnych części ciała samców i samic postrza łek były zgodne $\mathrm{z}$ rzeczywistymi wymiarami, z wyjątkiem ciężarów jąder i pęcherzyków nasiennych (Tabela 9). Każda część ciała w oparciu o swe alometryczne równanie (Tabela 9), była umieszczona w jednej z trzech wzorcowych klas wzrostowych. Alometryczne stałe ciężaru serca i nerek samców i samic były podobne do stałych innych dorosłych ssaków, a ciężaru wątroby znacznie wyższe (Tabela 10). 